\title{
A Group Interview about Publishing with Professor Jack Zipes
}

\author{
Emma Parfitt*, Emine Erdoğan, Heidi Fritz, Peter M. Ward \\ Department of Sociology, University of Warwick \\ *Correspondence: e.l.parfitt@warwick.ac.uk
}

Funding: See page 41

Peer review: This article has been subject to a double blind peer review process

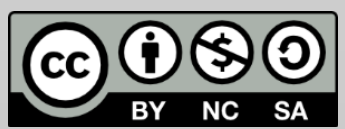

(c) Copyright: The Authors. This article is issued under the terms of the Creative Commons Attribution NonCommercial Share Alike License, which permits use and redistribution of the work provided that the original author and source are credited, the work is not used for commercial purposes and that any derivative works are made available under the same license terms.

\begin{abstract}
The conversation piece is the product of a group interview with Professor Jack Zipes and provides useful insights about publishing for early career researchers across disciplines. Based on his wider experiences as academic and writer, Professor Zipes answered questions from PhD researchers about: writing books, monographs and edited collections; turning a PhD thesis into a monograph; choosing and approaching publishers; and the advantages of editing books and translations. It presents some general advice for writing and publishing aimed at postgraduate students. Professor Zipes is an Emeritus Professor at the University of Minnesota Twin Cities, United States, a world expert on fairy tales and storytelling highlighting the social and historical dimensions of them. Zipes has forty years of experience publishing academic and massmarket books, editing anthologies, and translating work from French, German and Italian. His best known books are Breaking the Magic Spell (1979), Fairy Tales and the Art of Subversion (1983), The Irresistible Fairy Tale: The Cultural and Social History of a Genre (2012), and The Original Folk and Fairy Tales of the Brothers Grimm (2014).
\end{abstract}

Keywords: publishing, monograph, Zipes, thesis, writing, translation

\section{A unique publishing workshop}

Professor Jack Zipes, an Emeritus professor at the University of Minnesota, was invited to Warwick by Emma Parfitt, a researcher on oral storytelling (Parfitt, 2014; Parfitt, 2016), to participate in three days of events at the University of Warwick. Zipes' work has transformed research on fairy tales filling an important gap between folklore and literary studies by creating a social and historical analysis of fairy tales (Haase, 2002: 128-29). He has examined the work of writers like Hans Christian Andersen and L. Frank Baum and asked how have such authors rewritten and shaped fairy tales, but also how has social change influenced fairy tales. Zipes studied Political Science at Dartmouth College before completing an MA and a PhD in English and Comparative 
Literature at Columbia University. After this he taught German literature at the University of Minnesota until 2008. Zipes has forty years of experience publishing academic and mass-market books, editing anthologies, and translating work from French, German and Italian. His best known books are Breaking the Magic Spell (1979), Fairy Tales and the Art of Subversion (1983), The Irresistible Fairy Tale: The Cultural and Social History of a Genre (2012), and The Original Folk and Fairy Tales of the Brothers Grimm (2014). He has two books forthcoming, The Sorcerer's Apprentice (2017), and a book of 500 exclusive fairy tale illustrations in production out of a private collection of 2000 postcards.

On their first meeting in Cambridge in 2012, Zipes told Emma that he never expected to be an academic. He wanted to be a writer, and the prolific nature of his writing career demonstrates that he has successfully managed to be both an academic and a writer. Zipes has published over 15 books, edited 20, and translated academic theory and fairy tales from Italian, German and French (Gonzenbach and Zipes, 2004; Zipes, 2005). For example, he brought out a high quality translation of the Brothers Grimm (Zipes, 2014) which makes the earliest versions of the Grimms' tales available with all the gore and violence intact that the brothers edited out over the years. As such, Zipes is uniquely positioned to offer advice about how to approach publishers, the practicalities of putting together translations and edited books, and turning a PhD thesis into a book. This expertise in publishing inspired Emma Parfitt to create the event which offered a chance for PhD students to come along and ask any questions they wanted about publishing.

The event took place on 31 May 2016 and was entitled 'Ask Zipes about publishing'. Twelve students across English and Comparative Literature Studies, Sociology, WMG and the Warwick Business School registered to attend the event while Emma Parfitt, Emine Erdoğan, researching on gender in global food production (Erdogan, 2016), Heidi Fritz, studying gender activism in teachers' lives (Horzella, 2015), and Peter Ward, working on consumption-driven health supply chains in Sub-Saharan Africa (Ward and Kynvin, 2015; Ward and Sarley, 2014), asked questions about interdisciplinary publishing, turning a thesis into a book and translations based on their own experiences. With a fast-approaching REF (2020) and the demand placed on researchers to publish eligible research for REF, this paper can offer important insights to publish books, particularly to turn a PhD thesis to a monograph or to prepare edited collections, for early career researchers across disciplines thanks to the four interviewers' various questions. The reader can find guidance on the difference between the processes of publishing journal articles and monographs, information about approaching publishers and choosing 
the appropriate publisher for their research, and the advantages of editing books and translations.

The content has been edited to remove personal information about PhD researchers' ideas in progress that they would rather not be shared. For our international readers we would like to clarify that the word 'dissertation' refers to a doctoral thesis, 'defence' refers to viva voce, REF refers to 'Research Excellence Framework' a system assessing the quality of research in higher education in the United Kingdom, and an essay refers to a journal article or paper.

\section{The interview}

Emma Parfitt (EP): Thank you everyone for coming. The idea of this workshop was to provide the opportunity to ask an experienced academic questions about publishing in an informal setting. Professor Jack Zipes is visiting us from the University of Minnesota Twin Cities in the United States. He has published too many books to name, including edited anthologies of fairy tales, translations that he conducted himself, both in the academic and public sphere, so he has an amazing range of experience. I will start off the questions by asking a more general question that I think people will be interested in related to the PhD thesis. So to begin, what advice would you give to PhD students thinking about turning their thesis into a book?

Jack Zipes (JZ): Academia has changed a great deal. When I began the notion of 'publish or perish' did not exist. It has become very important. I think it is important to publish essays in respected journals. If you want to teach at a university a book is ten times, a hundred times more valuable than a paper. So I would encourage you to do that. What I have always recommended to my graduate students is that it is good to have an essay or two published, and it could be from your thesis, but never more than one part, a small part. Never more than two chapters, preferably never more than one chapter. Invariably you are going to have to rewrite. Examiners have other standards than book publishers. You may also have learned something from the viva. Educate yourself about which publishers to approach. You do not want to waste your time and send a letter of enquiry to a publisher that does not have a category for or care what you are writing about. You want to educate yourself by looking at books which have appeared, maybe in your bibliography. Who is publishing books on your particular topic. 
Peter Ward (PW): I can see that there is value in a book. I am aware that if you put too much material into a book then you may struggle to publish papers. How do we start to negotiate that?

JZ: If you do publish it as a book you will be ready to move onto another topic. You really want to finish the best you can. Then you're not limited. The reason I say a book is more important is that a book will probably get you what we in the States call a tenure track. I am not sure if it is the same over here.' Generally speaking, [in the United States] if you can get a book published and an academic position you are able to keep it. Once you are secure you do not have to rush into another publication you can do a paper or two. You are free to take your time and get some other publications. You may shift your interests. My field of study, my PhD, was in American and comparative literature of the eighteenth and early nineteenth centuries. Then I was Professor of German in comparative literature, developed an interest in folk and fairy tales, but I also did German theory. The wonderful thing about academia is once you have a steady position is that you can explore other fields. The first step is really important, to get your security somewhere and then see where you want to go.

PW: The next REF is fast approaching in 2020. There appears to be more emphasis given on papers than books...

JZ: Can I interrupt you? There are fields, economics for instance in the United States where they do not publish books. They publish long meticulous essays in established journals and one or two papers would be enough to get a tenure. So, your field was business, I do not know too much about that so it may be the same.

Heidi Fritz (HF): I would like to do a book that is not only academic. I would like anyone to have access to the book. What would be the difference between something academic and something for everyone?ii 


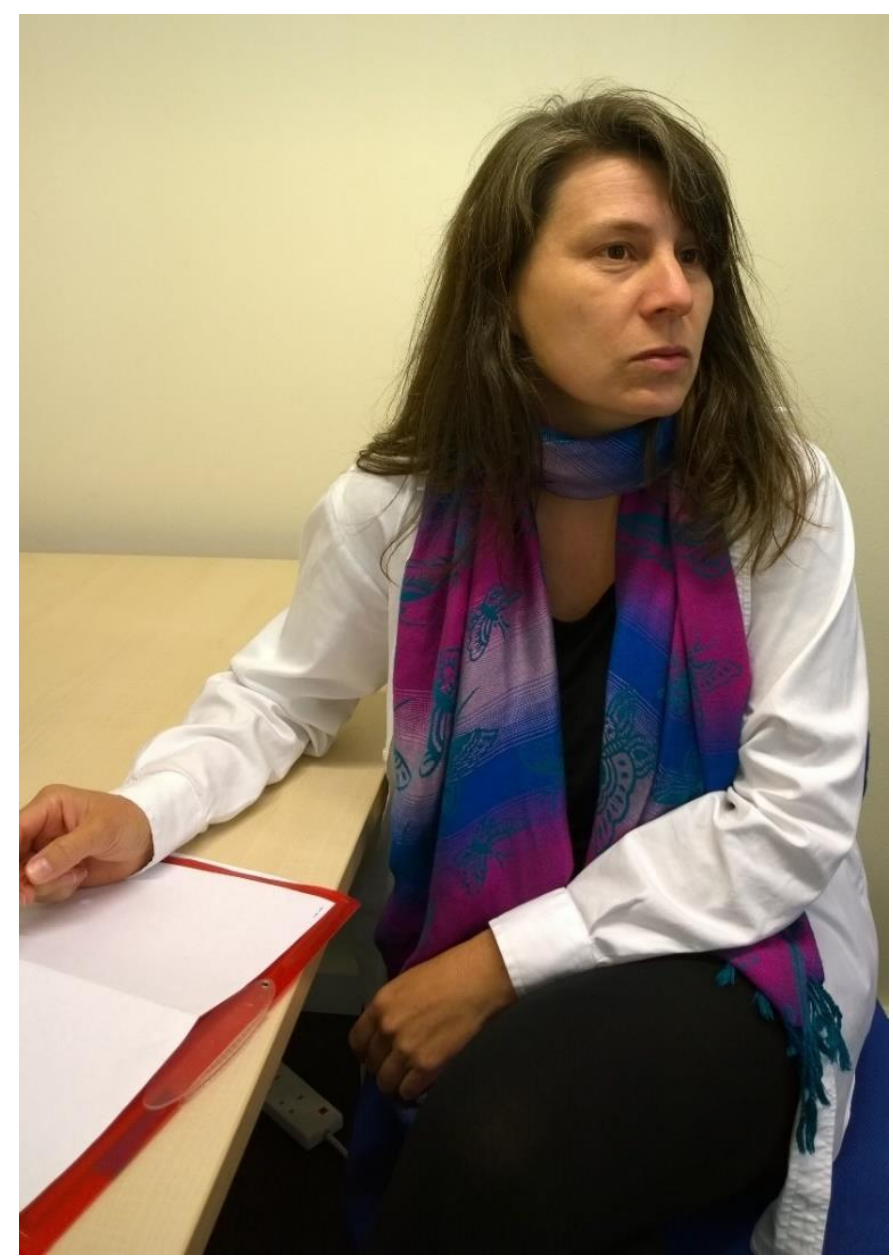

Heidi Fritz asking a question about translation. Source: Emma Parfitt.

JZ: Almost all the books that I have written have been for the general public. I published with Routledge early in my career. There are publishing houses of a very high quality that are not as academic as university publishers. You have to do your research and find out what are the publishing houses that want good scholarship and want someone who writes clearly, and can be understood by the general public while investigating very complex problems.

HF: My research and my fieldwork were based here in England with activist women teachers. So I was thinking to publish in English, to publish here. Perhaps then I can do something in my country, a comparative study, something like that, but where should I start?

JZ: Routledge is one of the places that I would begin with. Then there are numerous publishers in England that publish quality theoretical, and some atypical, topics. If a book is well written you should be able to find a publisher for it. If the topic is feminism you want to look into publishers that have already done some work on feminism. You do not want to neglect some university presses like Oxford ${ }^{\text {iii }}$ and Cambridge ${ }^{\text {iv }}$ because 
they are interested in mass-marketing, or trade, books for a large audience. Oxford and Cambridge are both welcome presses and do a good job of getting out books that are not normally academic. The other thing I would stress for both of you [Heidi and Emine] to be aware of the fact that you will be translators.

Emine Erdoğan (EE): I do not know, I haven't tried!

JZ: I would encourage you to. I speak German, French and Italian, and I have translated from all these languages. At times it is given me a little financial security. You might also want to translate your own books. Translating has been very beneficial to me, plus I love it. Some people don't. It is hard work but once you learn to translate well it is very important. ${ }^{v}$

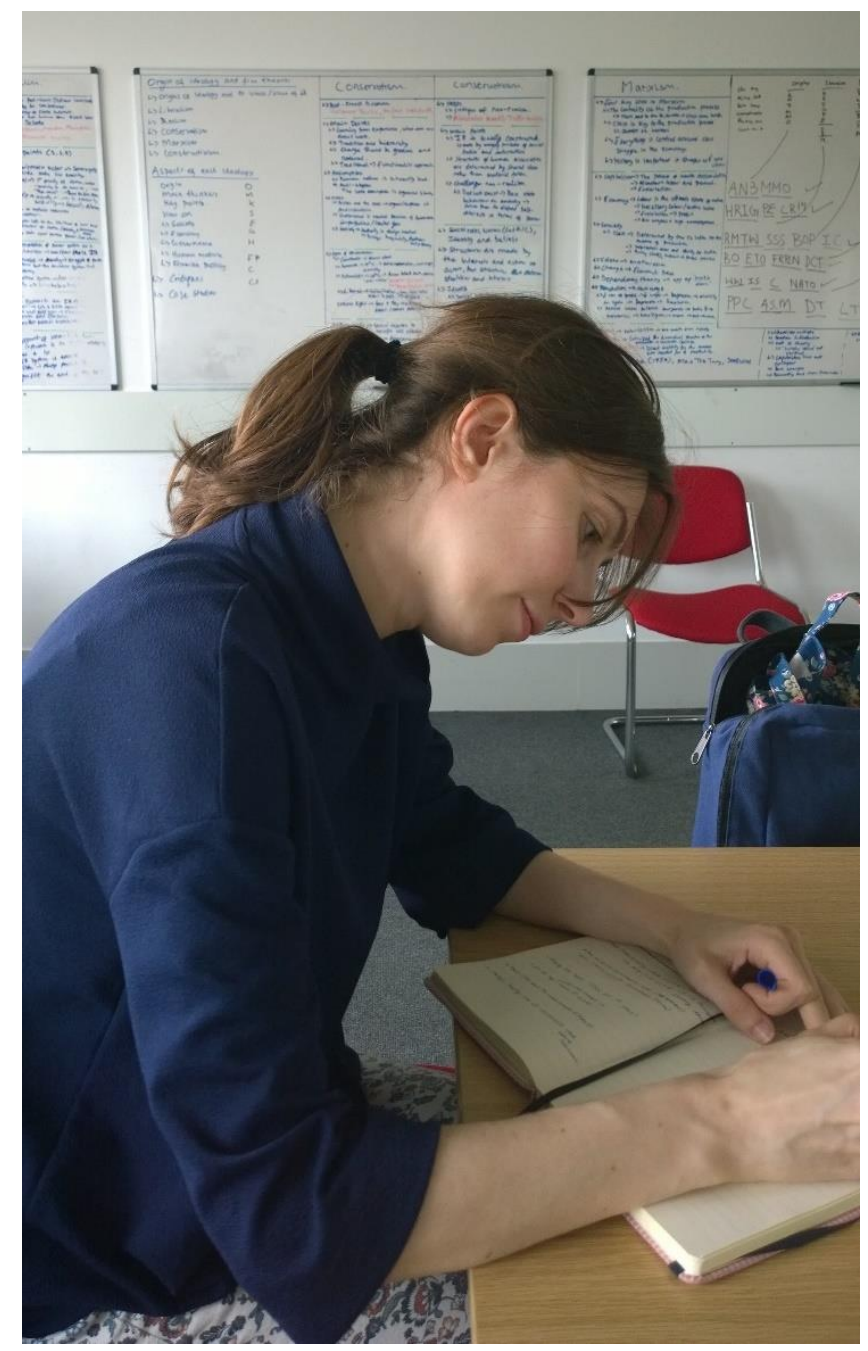

Emine Erdoğan making a note about edited books. Source: Emma Parfitt. 
EE: I have a question about edited books. I just submitted my thesis and I don't have any experience in any publishing. I come from Turkey. I had an idea for an edited book so I talked to a publisher and they accepted. I told them, 'I don't have any structure'. They said, 'Just try it' because there is no book for my idea. But I am a bit worried because I do not know anyone and I don't know how I can find someone for chapters to write, or if it is too early for me to start a project like this.

JZ: This would be a book published in Turkish?

EE: Turkish, yes.

JZ: And it would be a collection of essays? Not written by you but you would write an introduction and you would edit the rest. ${ }^{\text {vi }}$

EE: Yes.

JZ: That's a wonderful idea. Particularly if there is no book in Turkey that deals with this question. And by approaching different aspects you are guaranteed a good audience ${ }^{\text {vii. }}$. A lot of readers would be interested. Where are you now? You are almost done right, and you write in English?

EE: Yes, I have submitted. I wondered how I should approach the publisher.

JZ: It is somewhat easy. You have to do some homework. So translation maybe a good idea. Both in the UK and the United States there are tons of books on this topic. There are some classics, we might say pivotal essays. And so you may want to get permission from an American publisher to translate one, two or three essays. You have already established contact with a publisher who said they loved the idea right? So, you want to sign a contract with that, or get a letter of commitment. The reason I say that is because when you send a letter with a letterhead, depending on whether you have a job in Turkey or maybe you can use the letterhead of that publisher, you can write to other publishers directly. You write, and the publisher sometimes has a form that you can use, you write, 'Dear so and so, I am publishing' this book. Then say you are 'going to publish a collection of essays on' this topic. 'I would like to acquire the rights to publish this essay in my book'. Give the title. Say, 'It will probably be three hundred pages long. Please be aware that my budget is very small'. This is very important. 'If possible I would be grateful if I could have the rights for free. If not please inform me about how much the rights would be'. viii

You definitely want to get some pivotal, crucial, classical essays by wellknown people. Or not well-known necessarily but who have written really brilliant essays. Cause you want your book to be successful and there are some really good essays out there. You may want to divide your 
book into three or four sections like the history of the topic, the context in Turkey the context in the UK, then theoretical chapters and so on. It is important that it looks like you have the publisher behind you, that you are serious. Translation is important, you may want to do it yourself or supervise the translation which can be negotiated if you are able to do that. Then you write the introduction and you might want to write one of the smaller essays.

EE: Yes, I think so.

JZ: Another thing which requires a little more research is to read what has come out in Turkey. A university would be a beginning. Find who has written on different topics, then you want to invite them to participate in this book. And I am sure that most of them if you explain your budget would probably write it for nothing. If not, you could say if it makes any profits I will be able to pay you something for your essay. ${ }^{\text {ix }}$ If you have a good publisher who trusts you and you trust them the publisher can also give you advice into what the publisher can contribute. ${ }^{x}$

JZ: In the book that I am publishing in January 2017, The Sorcerer's Apprentice, I had to acquire ten different permissions for ten different fairy tales. It is an anthology. And I had to get a letter from my publisher in which they said 'we are going to charge this price, it is going to be 400 pages, and so on. I also had a sentence, 'I would appreciate you not charging me anything'. And in some cases we did not have to pay anything. The best way, I think, is through a publisher and they can help you.

EP: I have been reading different book proposals from different publishers. To try and get an idea of what they look like for submitting a proposal based on my thesis. They want things straight away and it is quite overwhelming when you've never done a book proposal before. For example, they want you to write the blurb that goes on the back of the book, unless I have misunderstood, and I thought that the publishing house would do this. Do you have any tips about where to start to do that?

JZ: Generally speaking, if you send out a book proposal quite often you can steal from your own proposal.

EP: They were asking for that as part of the proposal in the Routledge research proposal guidelines. Routledge asked for an abstract of 150-200 words included in the statement of aims outlining the rationale behind the book. 
JZ: It may be because they want to get some kind of concise idea of what is in your book, and why it is significant and what readers are intended ${ }^{\mathrm{xi}}$. Quite often when they accept the book they ask for a long summary for their marketing people, sometimes two to three paragraphs, sometimes a short paragraph that would appear on the back of the book.

EP: They asked for straightforward things like chapter outlines too.

JZ: The editor would have read your book but editors are tremendously overworked so once they have read the book, and got reviews for the book they have to move on. It is a very tough business publishing today. Non-academic books generally require an agent, though university presses generally do their own reading. . $^{\mathrm{ii}}$

EP: Coming back to what Heidi said about writing for a more general audience I have noticed that through the years, well, your first book Breaking the Magic Spell seemed more theoretical, harder to get into, than your subsequent books. Your language has become more clear and precise, easy to read. I wondered how do you get it to that stage?

JZ: A lot of work. [For example] feedback from the introduction to The Sorcerer's Apprentice, there is a whole section on theory, the introduction is 120 pages, then there are 400 pages of stories, tales. For me that is evidence of defence theory in the first part. I did have a big fight with an editor who wanted me to get rid of the theory in the introduction and I said 'no, I would make changes, and try to clarify certain things, but without this theory the book is worthless'. You know, without my introduction. You do get into fights and I have, I would not say simplify, but it is important to work at clarity. So I am grateful to an editor who says they don't understand what I am writing. I think if my editor who is highly educated cannot understand then maybe I am making a mistake. Maybe I need to rewrite this. I have learned over the years if I want to achieve my goal to have a highly educated and a general educated audience that I have to learn to make my writing accessible. One of the difficulties of my work, because I am steeped in German theory, is that their sentences go so long.

\section{HF: Long words!}

JZ: Yes, long words, and finally the verb comes at the end. It is not only that they wrote purposefully, the Frankfurt school, their writing is extremely complex and I have translated this... and some of my English, after years of living in Germany writing in German it affected my English. I write as well in German as I do in English. It does take, I generally like to send out parts of books and get some feedback from friends who I trust and they would say I think it is clear and not to worry, some of them will 
write long letters and say that this has to be changed or that has to be changed. I'm glad that I have become clearer over the years.

PW: [To Emma] What else did you notice in the requirements? I imagine chapter structure that kind of thing.

EP: Yes, they normally want a hundred words or so in layperson's terms about the focus of the book and why it is important. I imagine for a thesis it is important to focus on one idea and to emphasise it throughout the book. Also working title, chapter outline and who it is aimed at. So what your target audience is. They want to know for example if there are any courses at the university who would use the book. It depends on the publisher. Routledge for instance ask for chapter headings with detailed summaries; a definition of the market, a list of the main competing books and what product category it fits into that they already publish; a research schedule, so how long it will take to write it; and estimated manuscript length. .iii $^{\text {xii }}$

HF: I was thinking, going back to my work, which would be the difference between writing a thesis, an academic book, and a general public book in terms of how to think of the book? One thing I think of straight away is the language, making it more accessible to everyone. To tell it like a story.

JZ: What I and most of my colleagues at the university tell our PhD students when they are done with their dissertation is that the book has been written for academics who accept this very dry, very step by step, I am doing this I am doing that. So you do have to do heavy revising of your dissertation. You do not want to have the same dissertation especially if it is complex and there's theory; instead you want it to read like a story. You really want to try and find the most elegant style so that it will appeal to both a general reader and a specialist. It can be done. As Emma has pointed out, and I hope she is right, my style has changed during the years from somewhat dry and too complex to somewhat smoother. You have to work at it. We all want people to read us. Barring certain compromises, sometimes you have to draw a line and sometimes not. As I said before with my editor on this present book I'm not compromising but that rarely happens and generally speaking I will say okay. Even if it really hurts to take out this passage I found that it is best to listen to other people. I have never read a dissertation that would go to a publisher without being totally revised. It is not that difficult. You will want to step back a month or two after it is finished. You do not want to start revising straight away. You might want to take notes about the different points reviewers make during examination. Put those notes aside, put the dissertation aside, but not too long. Then go back and work on the dissertation and revise it. 
EP: Which reminds me that they asked in applications how long do you anticipate the book will take to finish, like a deadline? For an 80,000 word book for example how long do you think it would take?

JZ: It depends on the book. Generally 80,000 to a 100,000 words is a standard book of 250 pages or so. You should wait until you've revised your first chapter before you even approach, if you want to send it to a publisher. If you send a proposal they may want a chapter soon. First chapter, introduction...

\section{HF: How long does it take from a book proposal to a publication?}

JZ: Once they look at your manuscript and they say that they are very interested the next thing that they will do is send it out to two reviewers. Sometimes they will ask you for the names of some qualified people. That's great then you can use the names of people you can trust. Sometimes they won't, they will send it out. That will take two to three weeks before they find, they generally pay the reviewers and the reviewer does that within two months. Once they show an interest and find the reviewers it would be three months after you send everything. Then they'll make a decision. The reviewers will say, 'We will take the book but we would recommend this, this and this'. So you may still have to do some work revising. If two reviewers like your book $95 \%$ of the time your book will be published. It is a long process. Even after the reviewers liked the book and the editor says, 'We like the book, we want to publish the book and we'd like these changes'. Then you have to respond that, 'I am going to do this and this'. Then they go to their board and the editor says, 'This is where we are at, this is the response to the readers, do you approve?' At that point they send you a contract. The whole process of sending the manuscript, getting reviewers, having the book reviewed can take anywhere from months to a year. And then, once you have sent your manuscript it is another year. So unless you are very lucky and very powerful and very famous the book can take almost two years before it comes out. I have been lucky and I have had bad luck. The book The Sorcerer's Apprentice it was ready a few months ago but they have delayed publication until January 2017. I was hoping that it would come out this fall. I have been patient. Even at my stage it is a very unnerving process. I have been doing this for thirty or forty years. There are so many things that can go wrong. So many promises are broken or not kept. Whenever I submit something I say okay calm down, just be patient, this is not going to be fast. You learn patience.

PW: And you do not do it for the money, the royalties are fairly small I think. 
JZ: I have never done it for money. Almost all my books are very tiny. I have had tremendous luck. I was at a conference at Princeton University I think it was the mid-eighties: 1983 or 1984. After this conference a publisher from Princeton Press which is very big, very great, came up to me and says, 'We want to do the complete fairy tales of the Brothers Grimm. That is a book of 500 to 700 pages and would you be interested in doing it?' And I said, 'I'm sorry isn't there one out there?' She said, 'Not a recent one'. There was a recent one but it was a competitor and they wanted to dive into that market. I said, 'I tell you what there is an 1890 translation by Lucy Crane, the sister of the famous painter Walter Crane. I'll bring it up-to-date'. I looked at the translation but it was so bad that I said, I can't do that. I went back to her and she said, 'Please, please, please we really want to do it'. I was going on a sabbatical for a year in France and they said, 'We'll give you this percentage and a few thousand dollars in advance. I said that would help. I took the entire sabbatical doing the book. I'm working on this translation, I get back in June I had to work the entire summer and submitted it in the fall. I said good riddance. And they went really quickly into publication of the book and it came out the following spring. And they had a book of the month club and they bought it. Those days a book club like that sold thousands of copies. My next pay check I received a hundred thousand dollars.

PW: Wow!

EP: Thank you very much for your time, Jack.

JZ: You are welcome. 


\section{Acknowledgements}

Professor Jack Zipes' visit to the University of Warwick and Loughborough was made possible through a collaboration of resources brought together by Emma Parfitt, an IAS Early Careers Fellow, an IAS residential fellowship, the Humanities Research Centre, the Departments of Sociology, English and Comparative Literary Studies, and Professor Mike Wilson at the University of Loughborough.

\section{List of illustrations}

Heidi Fritz asking a question about translation. Source: Emma Parfitt. Photo reproduced by kind permission of Heidi Fritz.

Emine Erdoğan making a note about edited books. Source: Emma Parfitt. Photo reproduced by kind permission of Emine Erdoğan.

\footnotetext{
i Note for the reader about the current UK situation: From Lecturer level most university positions are permanent in the UK. The UCU and Higher Education Committee are taking steps to improve the conditions for the temporary staff and make permanent contracts the norm (UCU, 2016). See https://www.ucu.org.uk/stampout for detailed information about the current situation regarding casualisation of workforce in UK higher education.
}

\footnotetext{
ii While this question was not directly about open access, rather about how to write for a mix of educated and general interest readers, we thought it useful here to provide a short description in relation to disseminating research work to a wider audience. Open access has been defined as 'the principle that research outputs should be available freely, without restrictions on access or reuse, such as cost barriers or onerous copyright constraints' (Tickell, 2016: 7). Access the report for more detailed information here:

https://www.gov.uk/government/uploads/system/uploads/attachment_data/file/4994 55/ind-16-3-open-access-report.pdf. Note that in the 2020 REF open access articles will be submittable. To be eligible the Higher Education Funding Council for England (HEFCE, 2015) announced that journal articles and conference papers from 1 April 2016 onwards have to be submitted via a repository three months after the date of acceptance for publication. Further information about open access at the University of Warwick can be found here: https://www2.warwick.ac.uk/services/library/staff/research/open-access/.

iii Academic author's pages for Oxford University Press can be found at: https://global.oup.com/academic/authors/?lang=en\&cc=us

iv Preparing a proposal information for Cambridge University Press can be found here: https://authornet.cambridge.org/information/proposaluk/.

${ }^{v}$ In the 2014 REF there were some misconceptions that translations were not valued as highly as other academic texts. This has been criticised by members of the Modern Languages research community. For example, Harrison (2015: 5) argued, 'it has been
} 
possible to submit translations (and some academics have always done so), there has been a fairly widespread belief that translations will not be taken as seriously as other "outputs".' For those interested in translations for the 2020 REF the guidelines are not yet confirmed, but are likely to be the same as the 2014 REF. Translations these were treated as research in the 2014 REF (2012: 6-7) details of which can be found here: http://www.ref.ac.uk/pubs/2012-01/.

vi In addition to approaching a publisher directly to request permission to translate selected essays, organising a small workshop or conference to meet possible contributors could be very useful idea for someone desiring to prepare an edited book. Call for abstracts might also be very convenient way to attract possible contributors.

vii Although Professor Zipes refers here to a large variety of academic audience, it is necessary to admit that an edited book around particular topics attracts a comparably small readership.

viii For more information about publishing see Smith (2013) for being 'careful about what you sign', Clark and Phillips (2014) or Sugrue and Mertkan (2016) for advice about publications, or look at a particular publishers' webpage for their author guidelines such as Chicago University Press:

http://www.press.uchicago.edu/infoServices.html://www.press.uchicago.edu/infoServi ces.htmlhttp://www.press.uchicago.edu/infoServices.htmlhttp://www.press.uchicago.e du/infoServices.html

ix The authors caution the readers to be cautious to offer any profits when being uncertain about future sales

${ }^{x}$ Aspects that could be included in a letter/conversation with a publisher when approaching them about translating a text include the following: (1) State that you would like to translate the book/text [give precise details about the text and what language you would like to translate it into. (2) Provide some brief background about why you are qualified to do this translation. (3) Provide details of the publisher if one is already interested.

If a publisher who owns the essay/book rights want to charge for the rights, there are two options. First, to speak to the rights or permission department of your publisher, if you have one, about what they are able to offer. For example, they might acquire the rights. Second, explain that you would appreciate not being charged and see what the publisher (who owns the rights) offers in return.

${ }^{x i}$ In addition to Professor Zipes's comment, abstracts also serve to improve bibliometric retrieval and the metadata in bibliographic databases as well as libraries' online catalogues.

xii Note that it is possible to contact an academic publisher directly for a proposal outline about how to submit a book based on a thesis. If the information is not available online (which is rare) contact them directly and ask for their submission guidelines about converting a PhD into a book.

xiii Routledge's author guidelines can be found here: https://www.routledge.com/resources/authors/publishing 


\section{References}

Erdogan, E. (2016), "I pray for the factory to continue earning money': The familial factory regime of the 'Sun' food factory in Turkey,' Feminist Review, 113, 68-84.

Clark, G. and A. Phillips (2014), Inside book publishing. Fifth edition. London, New York, Routledge.

Gonzenbach, L. and J. Zipes (2004), Beautiful Angiola: The great treasury of Sicilian folk and fairy tales, New York: Routledge.

Haase, D. (ed.). (2002), English fairy tales and more English fairy tales, Santa Barbara: ABC-CLIO.

Harrison, N. (2015), Notes on translation in research. Modern Languages Open. Liverpool University Press, doi:10.3828/mlo.v0i0.78.

HEFCE (2015). Open access in the next Research Excellence Framework: policy adjustments and qualifications. Higher Education Funding Council for England, http://www.hefce.ac.uk/pubs/Year/2014/201407/.

Horzella, H. F. (2015), Women educators, leaders and activists.

Educational lives and networks 1900-1960, Gender and Education, 28(1), http://dx.doi.org/10.1080/09540253.2015.1057419, accessed 8 June 2016.m

Parfitt, E. (2014), 'Storytelling as a trigger for sharing conversations', Exchanges, 1(2),

http://exchanges.warwick.ac.uk/index.php/exchanges/article/view/25, accessed 7 June 2016.

Parfitt, E. (2016), Review of 'Comparative phylogenetic analyses uncover the ancient roots of Indo-European folktales', http://sociologicalimagination.org/archives/18525, accessed 8 June 2016.

Smith, K. (2013), What I learned getting published by Taylor \& Francis. Blog post. http://blogs.library.duke.edu/scholcomm/2013/04/23/what-ilearned-getting-published-by-taylor-francis/.

Sugrue, C. and S. Mertkan (2016), Publishing and the academic world; passion, purpose and possible futures. London, New York, Routledge.

Tickell, A. (2016), Open Access to Research Publications: Independent Advice,

https://www.gov.uk/government/uploads/system/uploads/attachment data/file/499455/ind-16-3-open-access-report.pdf, accessed 18 August 2016. 
UCU (2016), Stamp out casualisation, https://www.ucu.org.uk/stampout, accessed 3 June 2016.

Ward, P. M. and K. Kynvin (2015), 'Consumer-focused supply chains: a cross-case comparison of medicine appeal and acceptance in India, Uganda and Nigeria,' Warwick Manufacturing Group. April 1.

Ward, P. M. and D. Sarley (2014), 'Patient-centric healthcare supply chains in sub-Saharan Africa: State of the art and possible implications', Warwick Manufacturing Group. Service Systems Research Group Working Paper Series (03/14).

Zipes, J. (1979), Breaking the magic spell: radical theories of folk and fairy tales, London and New York: Routledge.

Zipes, J. (2005), The Norton Anthology of children's literature: The traditions in English, London: W. W. Norton \& Co.

Zipes, J. (trans. ed.) (2014), The original folk and fairy tales of the Brothers Grimm: The complete first edition. Jacob \& Wilhelm Grimm, Princeton: Princeton University Press.

To cite this article:

Parfitt, E., Erdoğan, E., Fritz, H., Ward, P. M. (2016). A group interview about publishing with Professor Jack Zipes. Exchanges: The Warwick Research Journal, 4(1) 29-44. Retrieve from:

http://exchanges.warwick.ac.uk/index.php/exchanges/article/view/116 